NBER WORKING PAPER SERIES

ON THE CONSISTENCY OF SHORT-RUN AND LONG-RUN

EXCHANGE RATE EXPECTATIONS

Kenneth A. Froot

Takatosh1 Ito

Working Paper No. 2577

NATIONAL BUREAU OF ECONOMIC RESEARCH

1050 Massachusetts Avenue

Cambridge, MA 02138

May 1988

*We thank Larry Summers for helpful discussion, Andy Berg and Joe Mullally for superb research assistance, and the Alfred P. Sloan foundation and the MIT UROP for generous financial support. The research reported here is part of the NBER's research program in International Studies. Any opinions expressed are those of the authors and not those of the National Bureau of Economic Research. 
NBER Working Paper \#2577

May 1988

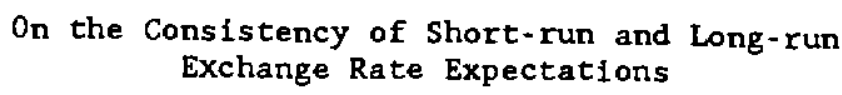

ABSTRACT

This paper examines whether short-term exchange rate expectations move "too much" by comparing them with long-term expectations. We develop a set of nonlinear restrictions linking expectations at different forecast horizons. The restrictions impose consistency, a property weaker than rationality. We use exchange rate survey data to measure expectations and then test whether consistency holds. The data show that a current, positive exchange rate shock leads agents to expect a higher long-run future spot rate whell iterating forward their short-term expectations than when thinking directly abont the long run. In this sense short-horizon expectations may overreact to current excliange rate changes.

Kenneth A. Froot Sloan School of Management

Massachusetts Institute of Technology Cambridge, MA 02139
Takatoshi Ito

Department of Economics, University of Minnesota Minneapolis, MN 55455 


\title{
On the Congistency of Short-run and Long-run Exchange Rate Expectations
}

\author{
Kenneth A. Froot \\ Sloan School of Management, \\ Massachusetts Institute of Technology \\ Cambridge, Massachusetts 02139 \\ Takatoshi Ito \\ Department of Economics, \\ University of Minnesota \\ Minneapolis, Minnesota 55455
}

\section{Introduction}

Much as the value of the dollar has fluctuated during the 1980 s, so too has the view that exchange rate determination should be left entirely to an unrestricted foreign exchange market. Only a decade ago, economists were nearly unanimıous in endorsing perfectly flexible exchange rates. In addition to Milton Friedman's (1953) persuasive argument that floating rates provided the least costly means of interuational adjustment, an avalanche of empirical work seemed to reaffirm economists' belief in free markets; empirical tests of spot and forward market efficiency were unable to reject, and a variety of models using sensible fundanientals appeared to explain inportant aspects of exchange rate behavior. But by the mid-1980s much had changed: simple efficiency tests had become powerful enough to reject regularly, ${ }_{1}^{1}$ and researchers turned pessinistic in their searcl for nlodels that could explain a positive fraction of exchange rate changes on the basis of fundamentals. The bleak situation was underscored by Meese and Rogoff's (1983) demonstration tliat a random walk, which cannot explain any positive portion of exchange rate changes, outperformed every nodel against which it was pitted. ${ }^{2}$

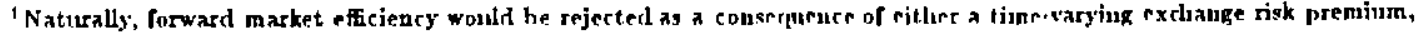
or a failure of rational expectations.

${ }^{2}$ Frankel ancl Donubusch (1987) containg a list of ways in which floatiug rxcliange rates liave failed to function as originally promiser.
} 
More recently, some economists have begun to revive older Keynesian views that expectations (and to some extent the currency values themselves) may sometimes be driven by animal spirits, and that the behavior of expectations may be responsible for many of the disappointments with floating rates. ${ }^{3}$ Short-term exchange rate expectations are often thought to fall prey to such forces. Nurkse (1944), for instance, is cited frequently for his fear that short-term expectations were subject to bandwagon effects: a contemporaneous depreciation in the spot exchange rate tends by itself to make speculators expect additional depreciation, potentially driving the spot rate further away from equilibrium.

Because expectations are unobservable, there is not mucl direct evidence on the way expectations behave. What little evidence we have, however, would appear at first glance to support Nurkse's suspicion. Frankel and Froot $(1987 \mathrm{~b}, 1988)$ use survey data on exchange rate expectations to estimate models of expectations formation and find that shorterterm expectations appear to exhibit the bandwagon effects described by Nurkse, while longer-term expectations do not. However, if agents form their expectations rationally, it is not clear why the mere presence of bandwagon expectations should be a source of concern. If, for example, the stochastic process generating the exchange rate displays positive serial correlation over short horizons, balldwagon expectations may rationally and passively reflect the behavior of the spot rate.

As one might expect, there is even less evidence that bandwagon expectations fail to be rational over short horizons. Frankel and Froot test, but are not able to reject, the hypothesis that bandwagon predictions are optimal if agents are limited to current and past exchange rate changes when forecasting future clianges. Indeed, there is other evidence that seems to support independently the rationality (or near rationality) of shortterın bandwagon expectations. Huizinga (1986) and Kaminski (1987) both find that the

\footnotetext{
On the behavior of exchange rates aud exchange rate expectations see Kinuman (1985), Fischer (1980), Dornbusch (1980), and tvilliamson (1986). In a more general context, a reimbrr of anthors have sngereted fliat "noise" traclers may appear to trade on the basis of expectations that are irrational and even umpreclictalile. Ser Dlack (1986), De Loug, Slueifer. Sunmers and tVa]rlman (1987), and Kyle (1985).
} 
stochastic process governing realized exchange rate changes displays positive serial correlation over short horizons." This finding, coupled with the sheer volatility of the spot rate, suggests that tests of rationality are likely to liave the problem of low power in distinguishing among nearby alternatives. ${ }^{5}$

A second problem in tests of rationality in the foreign exchange narket, besides low power, is that the usual confidence intervals may not be reliable. Infrequent but important events can create "peso problems" which make the distribution of the regression residuals far from nornal, and therefore produce misleading inferences in small samples. Indeed, the notion of peso problems has become so accepted that many recent empirical studies now conclude with partial disclaimers about the reliability of their findings in the presence of such problems. ${ }^{6}$ In much the same way, inference may be distorted through the presence of rational stochastic bubbles, ${ }^{7}$ unless the bubbles form and pop very frequently in the sample. ${ }^{8}$ In sun, the problems both of low power and nonnormal residuals in small samples tend to limit severely the force of any empirical evidence on the rationality of short-term expectations.

In this paper we use a different and potentially nore reliable metric to judge whether short-term expectations move too much: long-term expectations. That is, we test whether agents' expectations at different forecast horizons lead to equivalent predictions of the level of the exchange rate far into the future, a property that we call consistency. Short-term expectations may be said to be inconsistent relative to long-term expectations if a positive shock to the exchange rate leads agents to expect a higher long-run future spot rate when iterating forward their short-tern expectations than when thinking directly about the long run.

\footnotetext{
tliamiuski fincls that the real dollar exchange cate is positively correlaterl ovec intervala raugiug frum 1 to alsout b0 mouths, aud uegatively serially correlated nvec louger intervals. See also Poteclia and Suninece (1987) amil Lo aud Mlackinlay (1987)

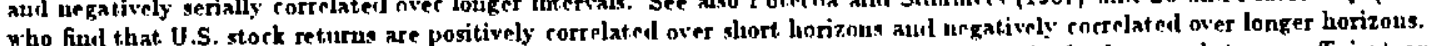

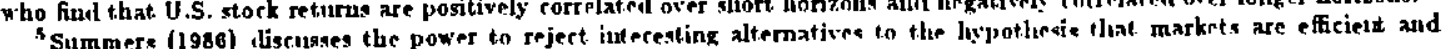
expected price changes are constant.

Examples inclucle Fama (1984), Hodrick (1987).

S See Blancliard (1979).

a Meese (1986), for example, uses nou-parametric methods to test for the preseuce uf hulblics. Sce also Olsatfeld (1987), who show how standard infecences may be incorrect in the jresence of both peso proble ma and stochastic lublules.
} 
Clearly, consistency is a necessary condition if expectations are to be rational. But consistency is weaker than rationality, since it does not require that the expectations process match the stochastic process generating the actual exchange rate. In addition, tests of consistency will be free of many of the statistical problems (such as those created by stochastic bubbles and peso problems) that plague tests of rationality. A failure of short-term expectations to be consistent would imply that even the agents themselves are not willing to live with the long-run implications of their own short-run forecasts.

Naturally, if we are to examine the behavior of expectations independently of the behavior of the actual spot process, we must rely on a measure of the expected future spot rate other than the future realization. Toward this end, we use data from three different surveys of exchange rate expectations. Each of the surveys simultaneously elicits expectations at several forecast horizons, allowing us to test whether the responses in each survey are consistent. In addition, the three surveys include a wide variety of forecast horizons, ranging from one week to one year. We can therefore gaill a sense for whether any inconsistency in the data pervades the term structure of agents' expectations, or whether it is confined to very short forecast horizons.

To preview our results, the statistical evidence presented below indicates that expectations do exhibit inconsistencies, although these inconsistencies appear less severe when comparing very short forecast horizons, such as one week and one montl. By contrast, both three- and six-month expectations appear to be very significantly inconsistent with expectations at the one-year horizon. However, in terms of ecollomic (rather than statistical) significance the data display a striking similarity across all forecast horizons and currencies: relative to longer-term expectations, shorter-term expectations invariably overreact to an exchange rate shock.

The rest of this paper is structured as follows. Section 2 defines the property of consistency and develops the cross-equation restrictions needed to test it. The results of our tests are presented in section 3 . Section 4 concludes. 


\section{Consistency}

Let $\mathbf{e}_{k, l+k}$ denote the $k$-period cliange between $t+k$ and $t$ in the $\log$ of the spot rate expressed in terms of dollars per unit of foreign currency. We denote the market's expectation at time $t$ of the log percentage change over the same period by $\mathbf{m}_{k, t+k}$. As in a vector-autoregressive inodel, we assume that one-period ahead expectations are formed as a linear combination of current and lagged spot rate changes, $\mathbf{a}_{1}(L) \mathbf{e}_{1, l}$, plus other residual factors that are conditionally independent of current and past exchange rate changes: ${ }^{9}$

$$
\mathbf{m}_{1, t+1}=\gamma_{1}+\mathbf{a}_{1}(\mathrm{~L}) \mathbf{e}_{1, t}+\mu_{1, t}
$$

where

$$
E\left(\mu_{1, t} \mid \mathbf{e}_{1, t} \ldots \mathbf{e}_{1, l-P}\right)=0
$$

$\mathrm{L}$ is the lag operator, and $P$ is the order of the autoregression. ${ }^{10}$ The assumption that $\mu_{1, l}$ is strictly orthogonal to current and past exchange rate changes is a strong one, although it is the usual assumption made when estimating vector autoregressions. Ironically, we are on relatively strong ground in this particular case: the failure of both past exchange rate changes and fundamentals ${ }^{11}$ to predict a positive portion of the current change indicates that exchange rate changes are serially uncorrelated as well as uncorrelated with current and lagged fundamentals. The lack of serial correlation suggests that our estimates will be robust to misspecification of $P$, while the inability of econounic fundamentals to explain exchange rate changes suggests that our estimates are robust to the specification and inclusion of these other factors.

Similar to equation (1), the market's expectation of depreciation over the subsequent $k$ periods is given by:

$$
\mathbf{m}_{k, l+k}=\gamma_{k}+\mathbf{a}_{k}(\mathrm{~L}) \mathbf{e}_{1, l}+\mu_{k, l}
$$

\footnotetext{
${ }^{9}$ The autoregressive repregentation iu equation (1) is expressed in cluabges loreause of the wrerwilieluing eviclence that the nominal spot rate contains a unit root.

in To avoid confusion with the notation used below, lefiue the operaten $E_{1}$ to yirltl the time-t expertation over the appropriate objective density function.

I' By funlamentals, we mean not ouly the staudard examples sucli as relative money supplies, output, aud interest rates, but also those which come out of newer exchange rate inodeis, such as the rnuclitional variances of mountary and fiscal policies (sce Hodrick, 1987).
} 
and we assume

$$
E\left(\mu_{k, \ell} \mid \mathbf{e}_{1, \ell} \ldots \mathbf{e}_{1, l-r}\right)=0
$$

Notice that the residual terms $\mu_{1, \ell}$ and $\mu_{k, l}$ in equations (2) and (4), respectively, do not include $e x$-post prediction errors, and are observable at time $t$.

We can express the upcoming spot rate change in terms of the same linear combination of current and past changes as equation (1), plus a new residual:

$$
\mathbf{e}_{1, t+1}=\gamma_{1}+\mathbf{a}_{1}(\mathrm{~L}) \mathbf{e}_{1, t}+\epsilon_{1, t+1}
$$

where $\epsilon_{1, t+1}=\mu_{1, t}+\eta_{1, t+1}$, and $\eta_{1, t+1}$ is the one-period prediction error made by the market. To move backwards from equation (5) to (1) we define the operator, $E_{l}^{\mathrm{m}}$, which yields the expectation over the market's subjective time-t conditional density function. The narket's prediction of the upcoming spot rate change can then be expressed:

$$
E_{l}^{\mathrm{m}}\left(\mathbf{e}_{1, \ell+1}\right)=\gamma_{1}+\mathbf{a}_{1}(\mathrm{~L}) \mathbf{e}_{1, t}+E_{l}^{\mathrm{m}}\left(\epsilon_{1, t+1}\right)
$$

where by construction, $E_{l}^{\mathbf{m}}\left(\mathbf{e}_{1, \ell+1}\right)=\mathrm{m}_{1, \ell+1}$ and $E_{l}^{\mathrm{m}}\left(\epsilon_{1, l+1}\right)=\mu_{1, l}$.

Note that if expectations are rational in the sense of Muth, then the market's conditional density function is equal to the objective conditional density function (conditioning on all information available at time $t), E_{l}^{m}()=.E_{l}($.$) . In that case, equation (6) repre-$ sents a standard vector-autoregressive model of excliange rate changes. Having made this assumption, we could estimate consistently the expectational parameter vector, $\mathbf{a}_{1}(\mathrm{~L})$, from equation (5) with ordinary least squares (OLS). However, if the subjective and objective densities are not precisely equal, then estimation of equation (5) will not generally produce consistent estimates of $a_{1}(L)$. In such a case it would not be appropriate to assume that the objective conditional expectation of the prediction error is equal to zero, $E_{t}\left(\eta_{1, t+1} \mid \mathbf{e}_{1, t} \ldots \mathbf{e}_{i-P}\right)=0$. Because we are interested in the particular linear combination used in forming expectations, we attempt to estimate equation (G) directly. This procedure is more general than one which relies on equation (5), since it allows for, but does 
not impose, the restriction that agents know the conditional density function of the actual spot process.

In order to develop our test of consistency, we need to express the long-horizon forecasts in equation (3) in terms of the parameters from equation (1). To do this we first rewrite equation (5) as a first-order autoregressive system:

$$
\mathbf{x}_{1, t+1}=\Gamma+\mathbf{A} \mathbf{x}_{1, t}+\epsilon_{t+1}
$$

which is given by

$$
\left(\begin{array}{c}
\mathbf{e}_{1, t+1} \\
\mathbf{e}_{1, l} \\
\vdots \\
\mathbf{e}_{1, l+1-P}
\end{array}\right)=\left(\begin{array}{c}
\gamma_{1} \\
0 \\
\vdots \\
0
\end{array}\right)+\left(\begin{array}{cccc}
a_{1,1} & \ldots & a_{1, P-1} & a_{1, P} \\
1 & \ldots & 0 & 0 \\
& \ddots & & \\
0 & \ldots & 1 & 0
\end{array}\right)\left(\begin{array}{c}
\mathbf{e}_{1, l} \\
\vdots \\
\mathbf{e}_{1, l-P+1} \\
\mathbf{e}_{1, l-P}
\end{array}\right)+\left(\begin{array}{c}
\epsilon_{1, l+1} \\
0 \\
\vdots \\
0
\end{array}\right)
$$

Consistency will involve restrictions on the companion matrix, $\mathbf{A}$.

By applying iteratively the subjective expectations operator to equation (7), it is straightforward to write the market's expectation of the change in the spot-rate vector, $\mathbf{x}$, between periods $t+j$ and $t+j-1$ :

$$
\begin{gathered}
E_{l}^{\mathbf{m}}\left(\mathbf{x}_{1, t+j}\right)=\sum_{i=0}^{j-1} \mathbf{A}^{i} \Gamma+\mathbf{A}^{j} \mathbf{x}_{1, t}+E_{l}^{\mathrm{m}}\left(\sum_{i=1}^{j-1} \mathbf{A}^{i} \epsilon_{l+j-i}\right) \\
=\left(\mathbf{I}_{P}-\mathbf{A}^{j}\right)\left(\mathbf{I}_{P}-\mathbf{A}\right)^{-1}+\mathbf{A}^{j} \mathbf{x}_{1, t}+E_{l}^{\mathrm{m}}\left(\epsilon_{l+j}^{\prime}\right)
\end{gathered}
$$

Equation (8) slows how any expected future one-period change in the spot rate can be expressed as a linear function of current and past exchange rate clianges.

Next we use equation (8) to form the expected $k$-period change given in equation (3). Note that the $k$-period expected change in the spot-rate vector from $t+k$ to $t$ is given by $\mathbf{x}_{k, t+k}=\sum_{j=1}^{k} \mathbf{x}_{1, t+j}$. Using this fact and equation (8) we liave:

$$
\begin{gathered}
E_{l}^{\mathrm{m}}\left(\mathbf{x}_{k, t+k}\right)=\left(k \mathrm{I}_{P}-\left(\mathbf{A}^{k+1}-\mathbf{A}\right)\left(\mathrm{I}_{\Gamma}-\mathbf{A}\right)^{-1}\right)\left(\mathrm{I}_{\Gamma}-\mathbf{A}\right)^{-1} \Gamma \\
+\left(\mathbf{A}-\mathbf{A}^{k+1}\right)\left(\mathrm{I}_{P}-\mathbf{A}\right)^{-1} \mathbf{x}_{1, l}+E_{t}^{\mathrm{m}}\left(\sum_{j=1}^{k} \epsilon_{l+j}^{\prime}\right),
\end{gathered}
$$


where by construction, $E_{l}^{\mathbf{m}}\left(\mathbf{x}_{k, t+k}\right)=\mathbf{m}_{k, l+k}$. Finally, define the $P \mathbf{x} 1$ selection vector, $\mathbf{g}^{\prime} \equiv\left(\begin{array}{llll}1 & 0 & \ldots & 0\end{array}\right)$. We now state the main proposition of the paper: ${ }^{12}$

Proposition: Given that short-term expectations are formed according to equation (1), long-term expectations are consistent if and only if the restrictions:

$$
\begin{gathered}
\gamma_{k}=\mathbf{g}^{\prime}\left(k \mathbf{I}_{P}-\left(\mathbf{A}^{k+1}-\mathbf{A}\right)\left(\mathbf{I}_{P}-\mathbf{A}\right)^{-1}\right)\left(\mathbf{I}_{\Gamma}-\mathbf{A}\right)^{-1} \Gamma, \\
\mathbf{a}_{k}^{\prime}=\mathbf{g}^{\prime}\left(\mathbf{A}-\mathbf{A}^{k+1}\right)\left(\mathbf{I}_{\Gamma}-\mathbf{A}\right)^{-1}, \\
\mu_{k, t}=E_{l}^{\mathrm{m}}\left(\sum_{j=1}^{k} \mathbf{g}^{\prime} \epsilon_{t+j}^{\prime}\right)=E_{l}^{\mathrm{m}}\left(\sum_{j=1}^{k} \sum_{i=1}^{j-1} \mathbf{g}^{\prime} \mathbf{A}^{i} \epsilon_{l+j-i}\right),
\end{gathered}
$$

are satisfied.

Provided that the assumptions given in equations (2) and (4) hold, the parameters in equations (1) and (3) can be estimated consistently using OLS.

To see how these restrictions operate, consider the simplest case in which agents use only the most recent change in the spot rate to predict the subsequent change, so that $P=1$. Then equation (11) yields only a single restriction, which reduces to $a_{k}=\sum_{j=1}^{k} a_{1}^{j}$. The long-term expected change is the sum of the individual expected changes, each of which is just the short-term expected change raised to a power equal to the number of periods it lies into the future. Note that as long as $\left|a_{1}\right|<1$, equation (11) implies that $a_{1}$ always has the same sign as $a_{k}$. If agents have short-term bandwagon expectations - by which we mean that they extrapolate positively past exchange rate changes into the future, $a_{1}>0$ - then they must have long-term bandwagon expectations if their expectations are to be consistent. Provided that the model in equation (1) is correctly specified and that $P=1$, evidence that short-term expectations are of the bandwagon type $\left(a_{1}>0\right)$ while long-term expectations are of the distributed lag type $\left(a_{k}<0\right)$ indicates inconsistency.

\footnotetext{
12 Similar cross-emution restrictions were imposed originally by Sargent. (1979) in a t.rct of the mxpectations hypothesis of the term stnicture of interest rates. See also Ito (1984), and Ito and Quah (1985).
} 


\section{Tests of Congistency}

\subsection{Data}

Our independent measure of the market's expected future spot rate is the median survey response from three ongoing exchange rate surveys. Each six weeks since mid-1981, the Economist Financial Report has polled currency-room traders and economists at 14 major banks for their views. They are asked to report their expected value of the dollar against five currencies (the pound, French franc, Deutsche mark, Swiss franc, and yen) in three, six and twelve months time. The second and third surveys bave been conducted on a weekly basis since early 1984 by Money Market Services (MMS). About 30 traders each week report their expectations of the value of the dollar against four currencies (the pound, Deutsche mark, Swiss franc, and yen) at horizons of one week and one month. The surveys conducted separately by the London and New York branches of MMS are of local traders' views, so that there is no overlap in respondents. We use these data sets to check for the possibility of different characteristics of investors on either side of the Atlantic. ${ }^{13}$ Table 1 summarizes the coverage of the survey data sets.

It is worth emphasizing that we do not have to treat the median survey response as though it were a perfect measure of the (unobservable) market expectation. The surveys may be subject to the same kinds of problems inherent in any proxy for this elusive variable. It seems reasonable to suppose that the median investor's expectation is an imprecise estimate of the market's expectation. When agents lave different beliefs but their demands can be aggregated into a single representative investor (which is the only way the concept of a unique "market" expectation makes any sense), individuals' expectations would be weighted according to risk tolerance or wealth (see, for example, Rubinstein, 1974). This implies that the median response will be an imprecise, but nevertheless unbiased, estimate of the aggregated expectation as long as risk tolerance and wealth are independent of individuals' beliefs about the rate of future depreciation. A second source of measurement

\footnotetext{
${ }^{12}$ For more det ail on these data sels, see Frauked and Froot (1987a) and Dominguez. (1986).
} 
error arises because only a subsample of the investing population is surveyed. As with any sampling method, the resulting measurement error will be purely random provided that the sample group's expectations do not differ systematically over time from those of the population.

Our estimation strategy allows for these sources of measurement error. Because the survey responses will be used only on the left-hand side of equations (1) and (3), any measurement error the surveys contain will end up in the contemporaneous residuals, $\mu_{1, t}$ and $\mu_{k, l}$, and will not affect our tests of consistency.

\subsection{Estimation}

We estimate systems of the form:

$$
\left(\begin{array}{c}
\mathbf{s}_{1, t+1} \\
\mathbf{s}_{k, t+k}
\end{array}\right)=\left(\begin{array}{c}
\gamma_{1} \\
\gamma_{k}
\end{array}\right)+\left(\begin{array}{ccc}
a_{1,1} & \ldots & a_{1, P} \\
a_{k, 1} & \ldots & a_{k, P}
\end{array}\right)\left(\begin{array}{c}
\mathbf{e}_{1, t} \\
\vdots \\
\mathbf{e}_{1, t-P}
\end{array}\right)+\left(\begin{array}{c}
\mu_{1, t} \\
\mu_{k, t}
\end{array}\right)
$$

where $\mathbf{s}_{1, l+1}$ and $\mathbf{s}_{k, l+k}$ represent the survey expected depreciation of the dollar against the foreign currency over the subsequent single period and $k$ periods, respectively, and $\mu_{1, t}$ and $\mu_{k, t}$ include any measurement errors in the survey medians. Before turning to the estimates, we discuss several econometric issues.

Point estinates of the parameters in equation (12) can be obtained using OLS. However, OLS will yield incorrect estimates of the standard errors because under the null hypothesis, the system residuals will display both contemporaneous and serial correlation. Contemporaneous correlation of $\mu_{1, l}$ and $\mu_{k, l}$ will occur because any "other" factors used in short-term forecasts are also likely to be used for long-term forecasts. Even if agents form their expectations by looking only at the past history of the spot rate, so that $\mu_{i, l}$ is purely random measurement error, these errors are likely to be contemporaneously correlated across forecast horizons.

Second, except in the extreme case in which the residuals are purely due to measurement error, serial correlation is also likely to be a problem. To see this, focus first 
on the long-horizon residual, $\mu_{k, t}$. Froin equation (12), consistency implies that $\mu_{k, t}=$ $E_{l}^{\mathrm{m}}\left(\sum_{j=1}^{k} \sum_{i=0}^{j-1} \mathbf{B}^{\prime} \mathbf{A}^{i} \epsilon_{t+j-i}\right)$. This term will in general be correlated with $E_{t+1}^{m}\left(\sum_{j=1}^{k}\right.$ $\left.\sum_{i=0}^{j-1} \mathbf{B}^{\prime} \mathbf{A}^{i} \epsilon_{l+1+j-i}\right)$ since by the law of iterated projections, the conditional expectation of a future variable follows a martingale. Note that this is true even if the realized short-term residuals are serially uncorrelated, $E_{t}\left(\mu_{1, t} \mu_{1,1+1}\right)=0$. In spite of the large measurement error component they no doubt contain, the short-horizon residuals will generally also exhibit correlation over time.

To correct for these problems, we use an extension of the GMM estimate of the parameter covariance matrix suggested originally by Hansen (1982) and modified by Newey and West (1985). This estimator allows for contemporaneous and noncontemporaneous correlations of unknown form (both across and within forecast horizons). In addition, within this framework it is straightforward to allow for conditional heteroskedasticity in the residuals as well. There is evidence, however, that heteroskedasticity-consistent covariance estimators may tend to bias the standard errors downward. Consequently, and in an effort to be conservative, we estimated both honloskedasticity- and heteroskedasticity-consistent standard errors and have reported only the larger of the two. ${ }^{14}$ To guarantee that our estimate of the covariance matrix is positive definite, we follow Newey and West (1985) by discounting th order autocovariances by $1-l /\left(T^{.25}+1\right)$, where $T$ is the number of time-series observations.

In order to specify the lag length $P$, we began with $P=1$ and increased it incrementally. In almost all cases the higher order lags above $P=2$ were both economically and statistically insignificant. We present estimates for both $P$ equal to 1 and 2 , although the qualitatively nature of the results does not depend on the precise value of $P$.

\subsection{Regression Results}

Our first set of tables contains estimates of the system described by equation (13) for

\footnotetext{
14 In the results below the stanclard errors calculated usiug these two urethods differed lyg a markin of less than ten percert. See Froot (1987) for evidence on the downward finite sample bias of heternakedastirity.rousintent standard ertors.
} 
the case in which $P$ is set to 1 . The second set allow $P$ to be 2 . In order to gain a sense for the economic inportance of our formal consistency tests, we turn in the second part of this section to a set of figures which display the impact of a contemporaneous exchange rate shock on expected future spot rates.

Table 2 reports the regression results for the five currencies included in the Economist survey for the case in which $P=1$. The forecast horizons for this survey are three, six and twelve months, so that the system in equation (13) must be extended to allow for three equations instead of two. Table 2 shows that the coefficients on the current exchange rate change, $a_{i, 1}, i=3,6,12$, are statistically less thall zero. In the case of the British pound, for example, the point estimates imply that a 10 percent dollar appreciation over the past three months leads to an expected depreciation of 1.5, 2.0, and 2.8 percent over the following three, six and twelve months, respectively. The coefficients for the other currencies are similar. The last column in Table 2 reports a Wald test of the consistency restrictions given in equations (11) and (12). The data reject consistency for all five currencies.

Tables 3 and 4 , respectively, report the results for $P=1$ from the New York and London surveys conducted by MMS. Note that the forecast horizons are now shorter, at one week and one nonth. In both of these tables, most of the coefficients are positive, indicating the presence of a bandwagon effect. At the one week horizon, 6 out of 8 of these are statistically positive at the five percent level. By comparison, only one of the one-nonth coefficients is statistically positive and, while some are negative, none is statistically less than zero. In the case of the British pound, the coefficients reported in Table 3 imply that a 10 percent dollar appreciation over the past week leads on average to expectations of an additional 1.0 percent appreciation over the following week and a 0.1 percent appreciation over the following month. In these tables, there is little evidence against consistency: only one of the Wald tests rejects at the five percent level. We nevertheless investigate the implications of the point estimates below. 
We cannot test formally the consistency restrictions across data sets, since the models are not nested. Nevertheless, it is important to note that, for all of the currencies, only the shorter-term expectations at the one-week and one-month horizons are related positively to the past exchange rate change. Bandwagon expectations do not appear, however, at any of the longer horizons: the coefficients are negative. Thus, even though we cannot test formally the hypothesis that across surveys the coefficients are the same, the point estimates decline systematically and substantially as the forecast horizon is increased. As we will see in the graphs below, the fact that the short-term estimates are negative and long-term estimates are positive indicates that the slort-terul expectations will overreact in comparison with long-term expectations.

Tables 5, 6, and 7 present estimates for each of the three surveys when $P$ is set to 2 . While in some cases the added coefficients are statistically significant, they have no effect on the $a_{i, 1}$ coefficients reported in Tables 2,3 , and 4 . The Wald tests for the Economist data in Table 5 continue to reject the null hypotlesis that expectations are consistent. The New York MMS data set in Tables 6, however, now rejects consistency restrictions in 2 out of 4 currencies (the Swiss franc and yen), both at significance levels of five percent. The London MMS data in Table 7, however, do not reject the hypothesis of consistency for any of the currencies.

\subsection{Graphical Regults}

Because of the complexity of the cross equation restrictions given by equations (11) and (12), it is difficult to interpret the economic importance of eitler the Wald test statistics or the parameter estimates in Tables 2 through 7 . In this section we therefore look at the graphical implications of our results for the future spot rate path. The pictures can give us a sense (which a Wald statistic cannot) both of the qualitative importance of any inconsistencies, and, nore importantly, for whether consistency fails because short-term expectations move too much or too little with respect to long-term expectations.

Consider the following experiment. Assume the exchange rate is a steady state in 
which current and past exchange rate changes are equal to zero. ${ }^{15}$ We then shock the spot rate and trace out its expected future path as implied by both the short- and long-horizon forecasts. The graphs of these experiments are presented below. ${ }^{10}$

Figures 1 through 5 depict the expected future path for each of the five currencies in the Economist survey in the case where $P=1$. The initial exclange rate appreciation is one percent. All of the figures show that the ultimate expected effect of an exchange rate shock depends substantially on whether three, six, or twelve month expectations are iterated forward. For example, the paths in Figure 1 for the British pound imply that when the current spot rate is perturbed by 1.0 percent, the long-run spot rate predicted by the three-month expectations is $(.88-.80) / .80=0.10$ percent higher than the long-run level predicted by the six-month expectations, and $(.88-.72) / .72=0.22$ percent higher than the long-run level predicted by the twelve-month expectations. Across all five graphs, a clear pattern emerges: a positive exchange rate shock generates a higher expected long run value of the spot rate when shorter-run expectations are used than when longer-run expectations are used. Notice, however, that for all three forecasting equations, part of the original one percent dollar appreciation is undone, so that the long-run value increases less than proportionately in response to current shocks.

Figures 6 through 9 , and 10 through 13 show the expected future patli when $P=1$ for the New York and London MMS data sets, respectively. As a group these graphs exhibit two distinctive properties. The first is that within each data set, the one-week expectations overreact to an exchange rate shock in comparison with the one-month expectations. This is the same pattern we saw above. The second distinctive feature of these figures involves a conparison with the Economist graphs. In the MMS data sets, the long run equilibrium

\footnotetext{
${ }^{15}$ In order to focus on the dynamics of the system, we set the constast terms in erpuation (13) equal to arro in this experimeit.

16 The patha are constructed by iterating each forecast eriation forward, aud applying the ronditioual expectation operator. From equation (1) it is easy to see that uging the short forecast horizon $(k=1)$ we can gellerale cousecutive future expected changes. Note that at longex forecast horizons of, say, $k$ periods, forecast, of the spot rate $k, 2 k, 3 k, \ldots$, periods in adiance are prodiced by equation (3). However, even when $P=1$, these forecasts, themselves recpure forerasts of the spot rate change in $2 k-1,3 k-1, \ldots$, periods into the future. Fe useil the preclictions from the short-lionizon erguation for the expected change between periods $n k$ and $n k-1$. This procedure is unbiaged uncler phe unll hylontheris, aldich states that expectatious are consigtest. If expectations are uot consistem, then thls method teuls in minimize the nhservil rleviatious from consisteucy.
} 
spot rate increases more than proportionately in response to an exchange rate shock. This is a pattern precisely opposite to that demonstrated in the Economist data. Nevertheless, it is still consistent with the finding that shorter-term expectations appear to be more sensitive to exchange rate shocks that are longer-term expectations.

Graphs 14 through 26 parallel exactly the earlier set, with $P$ set to 2 . The qualitative results are the same here as when $P$ was fixed at 1 . If anything the increase in the order of the distributed lag increases the visual appearance of the overreaction of short-term forecasts relative to long-term forecasts (especially in the MMS data, Figures 6-13 and 19-26). 


\section{Conclugiong}

We have derived a property, called consistency, which all rational forecasts have, but which itself does not require rationality. Our tests using survey data on exchange rate expectations indicate that expectations generally fail to be consistent. Most striking is the particular way in which investors fail to coordinate their predictions: in their shorter-term forecasts, investors tend to exaggerate the implications of current exchange rate changes for the value of the spot rate further into the future. If longer-term forecasts are used as the norm, shorter-term expectations overreact to current exchange rate changes.

One possible way to explain the failure of expectations to be consistent is to think of agents using different models to forecast the spot rate at short versus long horizons, and a blend in between. Frankel and Froot (1986), for example, model the expectations of "chartists" and "fundamentalists" and suggest that agents form expectations by weighting these views according to their own expected trading horizon (with chartist views more important for short horizons, and fundamentalists views more important for long horizons). But obviously, no single explanation of our findings can be completely satisfying, since a failure of consistency implies that expectations cannot be rational.

A second way to explain the rejections of consistency wonld be that the survey data systematically mismeasure the market's true expectation. ${ }^{17}$ If, for example, agents report repeatedly the mode rather than the mean of their subjective distribution, then there is no reason that consistency should hold in these data. Nevertheless, when we tried to test the restrictions developed above using the forward discount in place of the survey measure of expected depreciation, we found results similar to those reported in Tables 2 through 7. We do not present these results, however, because of the difficulty in interpreting them in view of the likely contamination of the forward market data by an exchange risk premium. ${ }^{18}$ Nevertheless, one could interpret these results as suggesting that the

\footnotetext{
${ }^{17}$ We are grateful to Larry Summers for the following point.

"In the forward market test, the coefficients were smaller in alsoolute value thau those presented in Tahleg $2 \cdot 7$, but very similar in sign and atatiotical significance. In addlitinn, the resills of congistency lests were similar to thone reported above.
} 
explanation for inconsistency found in the survey data is not solely a result of a tendency to mismeasure expectations.

One important caveat to keep in mind when interpreting our tests is that the expectations process may not be described completely by the observable history of spot rate changes. If other variables matter for expectations, then our results may be biased, although it is not obvious why the bias would produce the persistent appearance of overreaction in short-term expectations. 


\section{References}

Black, Fisher, "Noise," Journal of Finance, Vol. 41, 1986, pp. 529-43.

Blanchard, Olivier, "Speculative Bubbles, Crashes and Rational Expectations," Economics Letters, 1979, pp. 387-89.

De Long, Bradford, Andrei Shleifer, Lawrence Summers, and Robert Waldman, "The Economic Consequences of Noise Traders," NBER Working Paper No. 2395, October 1987.

Dominguez, Kathryn, "Are Foreign Exchange Forecasts Rational: New Evidence From Survey Data" Economics Letters, Vol. , 1986, pp.

Dornbusch, Rudiger, "Flexible Exchange Rates and Excess Capital Mobility," Brookings Papers on Economic Activity, Vol. 1, 1986, pp. 209-27

Dornbusch, Rudiger, and Jeffrey Frankel, "The Flexible Exchange Rate System: Experience and Alternatives," NBER Working Paper No. 2464, December 1987.

Fama, Eugene, "Forward and Spot Exchange Rates," Journal of Monetary Economics, Vol. 36, 1984, pp. 697-703.

Fischer, Stanley, Discussion in Brookings Papers on Economic Activity, Vol 1., 1986, pp. 227-35.

Frankel, Jeffrey, and Kenneth Froot, "Using Survey Data to Test Standard Propositions Regarding Exchange Rate Expectations," American Economic Review, Vol. 77, 1987a, pp. 133-53.

"Short-term and Long-term Expectations of the Yen/Dollar Exchange Rate: Evidence from Survey Data," Journal of the Japanese and International Economies, Vol. 1, 1987b.

"Explaining the Demand for Dollars: International Rates of Return, and the Expectations of Chartists and Fundamentalists ${ }^{n}$ Economics Working Paper No. 8603, U.C. Berkeley. In Chambers, R. and Paarlberg, P. (eds.), Agriculture, Macroeconomics and the Exchange Rate, forthcoming, 1988.

Friedman, Milton, "The Case for Flexible Exchange Rates," in his Essays in Positive Economics, Chicago: University of Chicago Press, 1953, pp. 157-203.

Froot, Kenneth, "Consistent Covariance Matrix Estimation with Cross-Sectional Dependence and Heteroskedasticity in Cross-Sectional Financial Data," NBER Technical Working Paper No. 62, August 1987. 
Hansen, Lars, "Large Sample Properties of Generalized Method of Moments Estinators," Econometrica, Vol. 50, 1982, pp. 1029-54.

Hodrick, Robert, "Risk, Ullcertainty and Exchange Rates," NBER Working Paper No. 2429, Novenber 1987.

Huizinga, John, "An Empirical Investigation of the Long-Run Behavior of Real Exchange Rates," Carnegie-Rochester Conference Series on Public Policy Vol. 27, 1987, pp. 149-214.

Ito, Takatoshi, "Use of (Time-Domain) Vector Autoregressions to Test Uncovered Interest Parity," The Review of Economics and Statistics, (forthcoming), 1987.

Ito, Takatoshi, and Danny Quah, "Hypothesis Testing with Restricted Spectral Density Matrices, with an Application to Uncovered Interest Parity," NBER Technical Working Paper, no. 50, 1985, and forthcoming, International Economic Review,

Kaminski, Graciela, "The Real Exchange Rate in the Short Run and the Long Run," University of California, San Diego, 1986.

Krugman, Paul, "Is the Strong Dollar Sustainable?," in The U.S. Dollar: Recent Developments, Outlook, and Policy Options, Federal Reserve Bank of Kansas City, 1985.

Kyle, Albert, "Informed Speculation with Imperfect Competition," Princeton University, 1985 .

Lo, Andrew and Craig MacKinlay, "Stock Prices do not Follow Random Walks: Evidence from a Simple Specification Test, ${ }^{n}$ NBER Working Paper No. 2168, February 1987.

Meese, Richard, "Testing for Bubbles in Exchange Markets: A Case of Sparkling Rates?," Journal of Political Economy, Vol. 94, 1986, pp. 345-73.

Meese, Richard, and Kenneth Rogoff, "Empirical Excliange Rate Models of the Seventies: Do They Fit Out of Sample?," Journal of International Economics, Vol. 14,1983 , pp. 3-24.

Newey, Whitney, and Kenneth West, “A Simple, Positive Definite Heteroskedasticity and Autocorrelation Consistent Covariance Matrix," Woodrow Wilson School Discussion Paper No. 92, 1985.

Nurkse, Ragner, International Currency Experience, Geneva: League of Nations, 1944.

Obstfeld, Maurice, "Peso Problems, Bubbles, and Risk in the Empirical Assessment of Exchange Rate Behavior," NBER Working Paper No. 2203, April 1987. 
Poterba, James, and Lawrence Summers, "Mean Reversion in Stock Prices: Evidence and Implications," NBER Working Paper No. 2343, August 1987.

Rubinstein, Mark, "An Aggregation Theorem for Securities Markets" Journal of Financial Economics, Vol. 1, 1974, pp. 225-244.

Sargent, Thomas J. “ A Note on Maximum Likelihood Estimation of the Rational Expectations Model of the Term Structuren Journal of Monetary Economics, Vol. 5, 1979, pp. 133-143.

Williamson, John, "Target Zones and Management of the Dollar," Brookings Papers on Economic Activity, Vol 1., 1986, pp. 165-74. 
TABLE 1

Description of Data

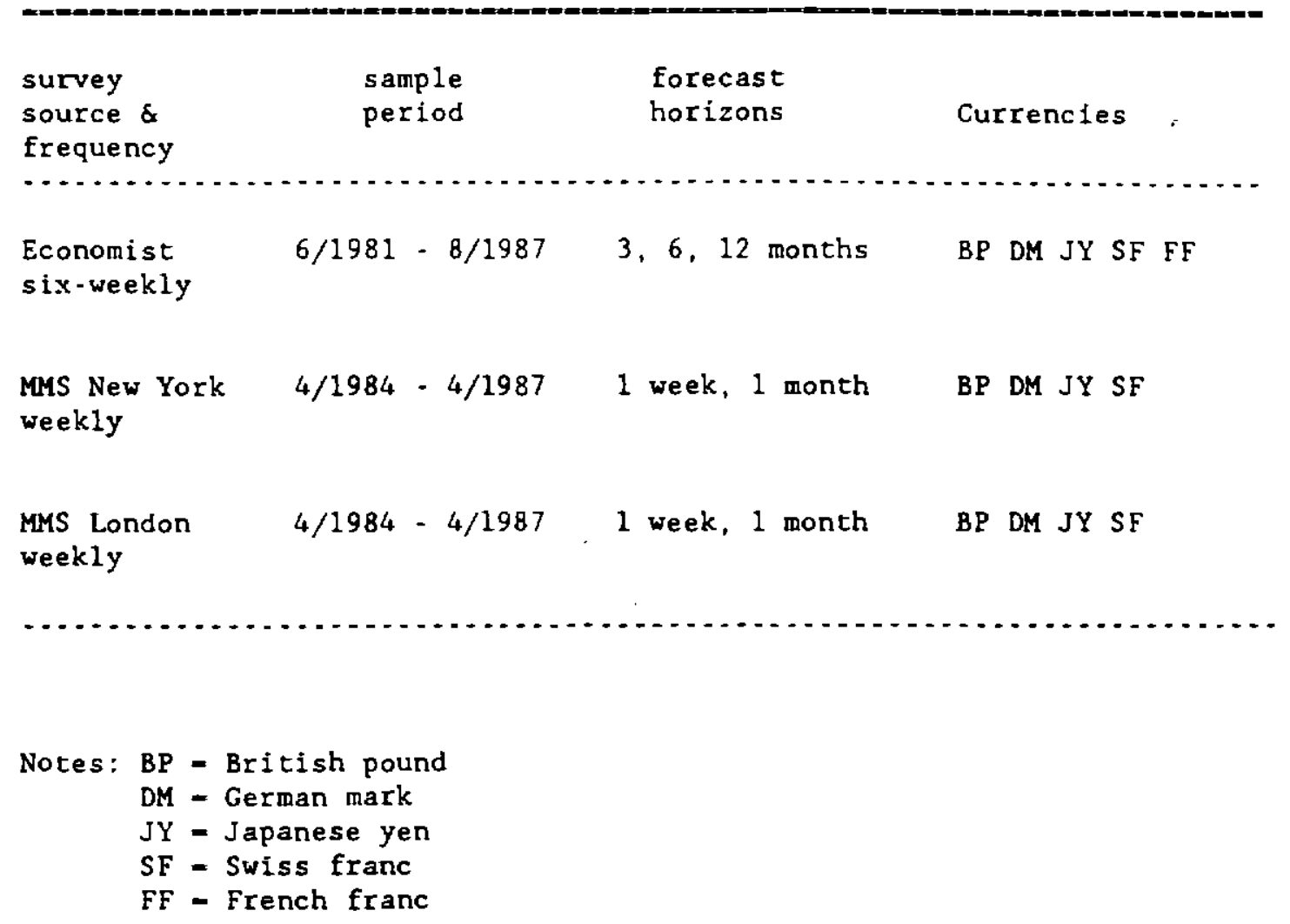


Figure 1

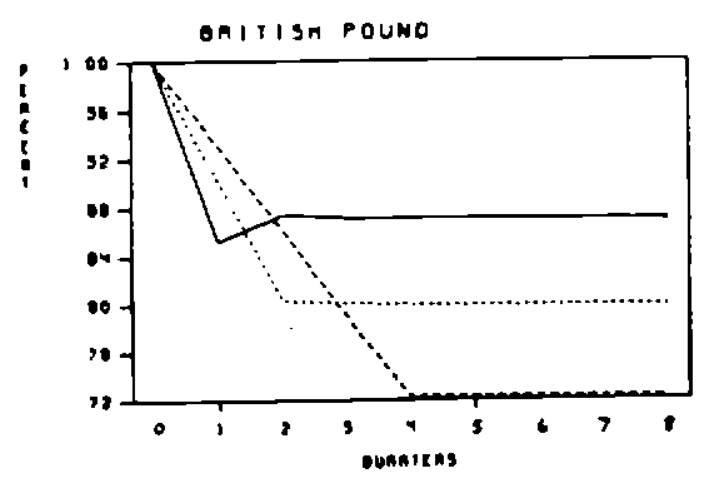

Figute 3

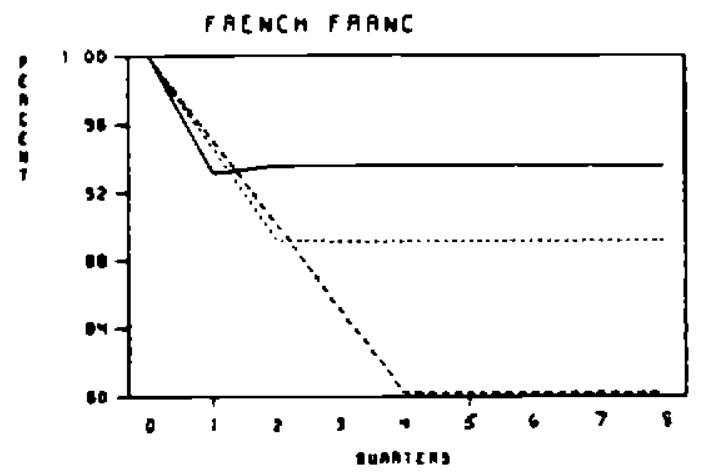

Flgure 5

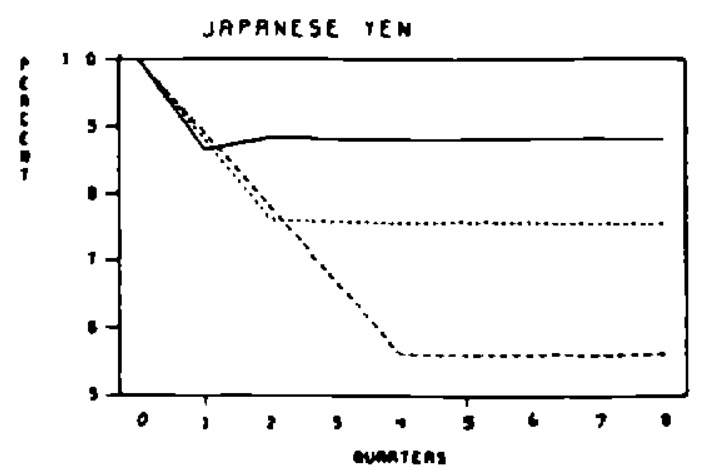

Figure 2

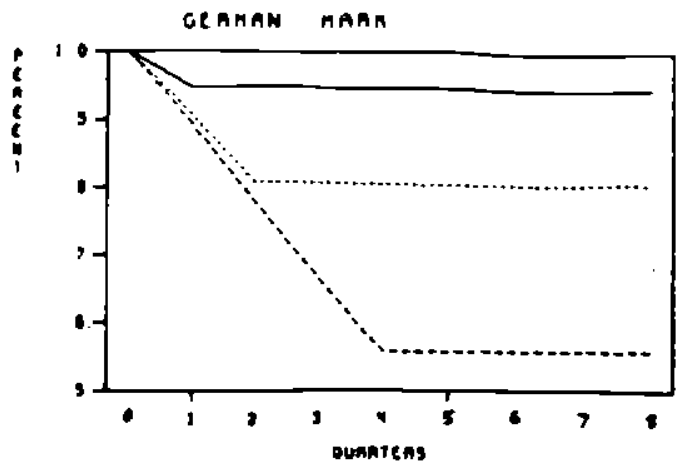

Figure 4
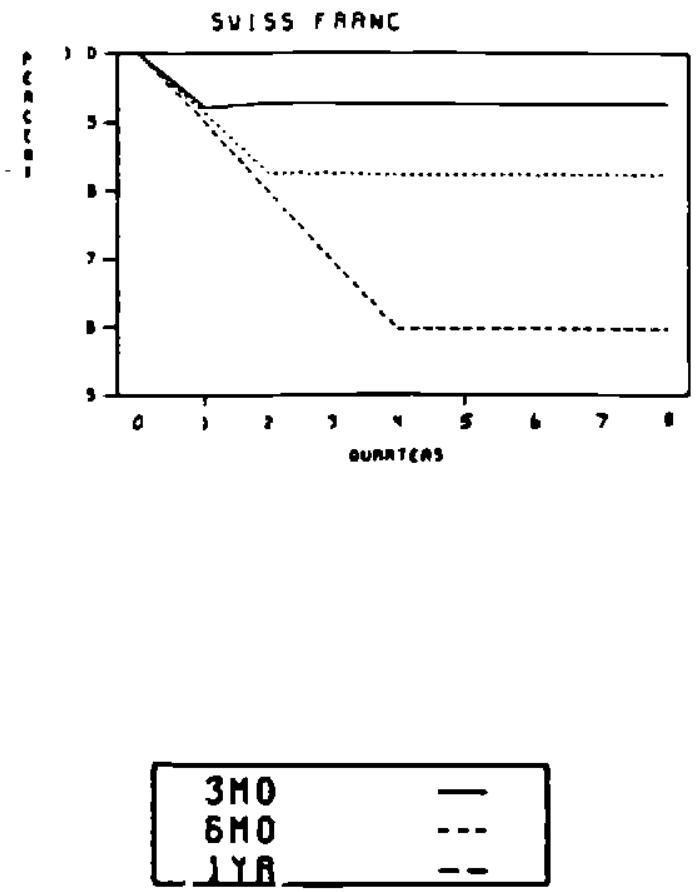
MAS NEW YORK DATA

Figure 6

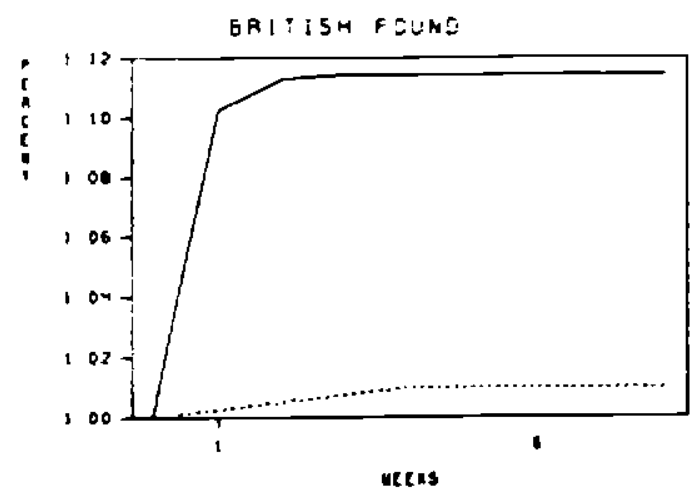

F1gure 8

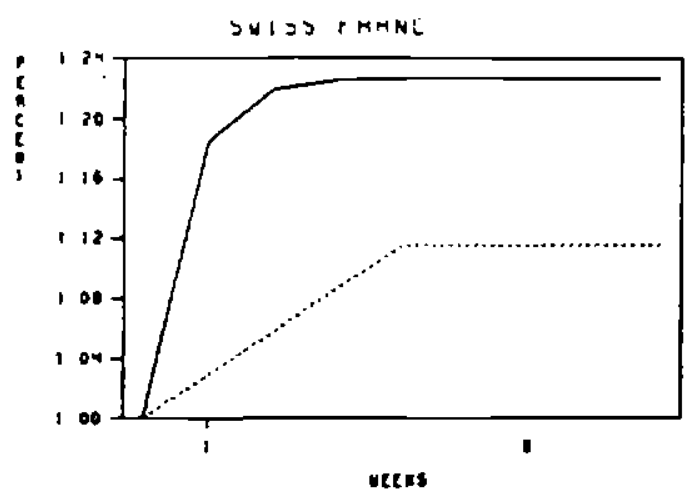

Figute?

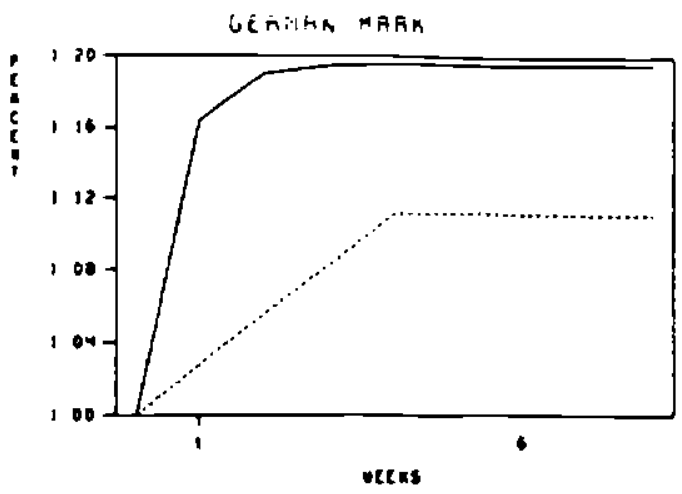

F1gure?

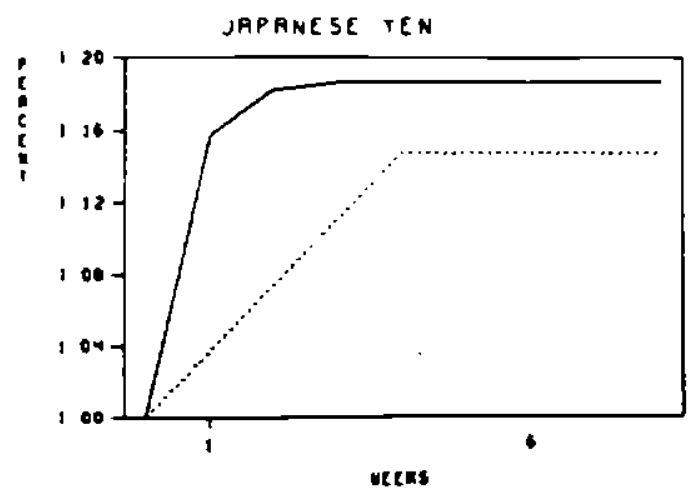
$14 x$
ino
$\ldots$ 
MAS LONDON DATA
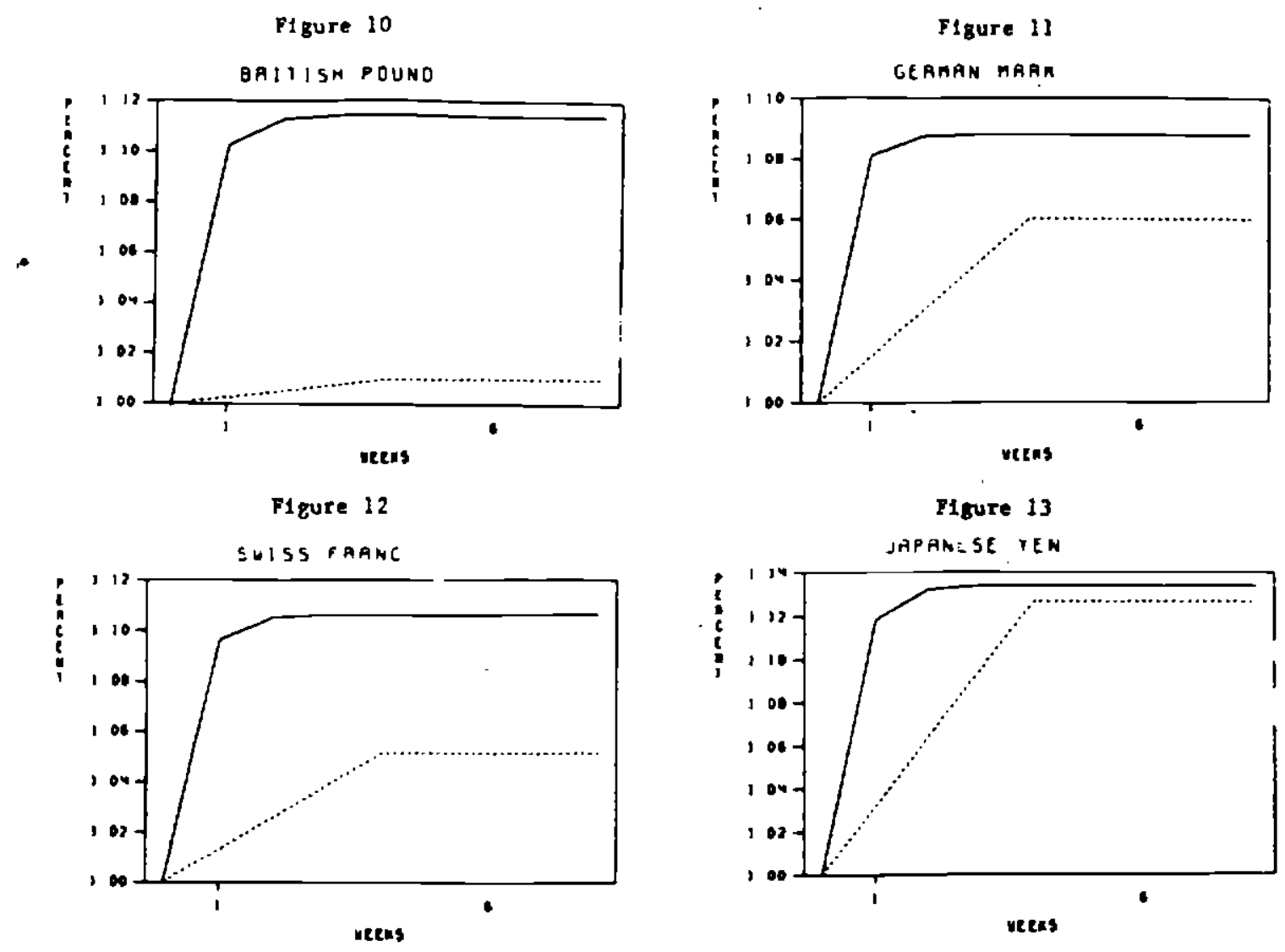

\begin{tabular}{|ll|}
\hline $14 K$ & - \\
INO &..- \\
\hline
\end{tabular}


ECONOMIST DATA

Figure 14

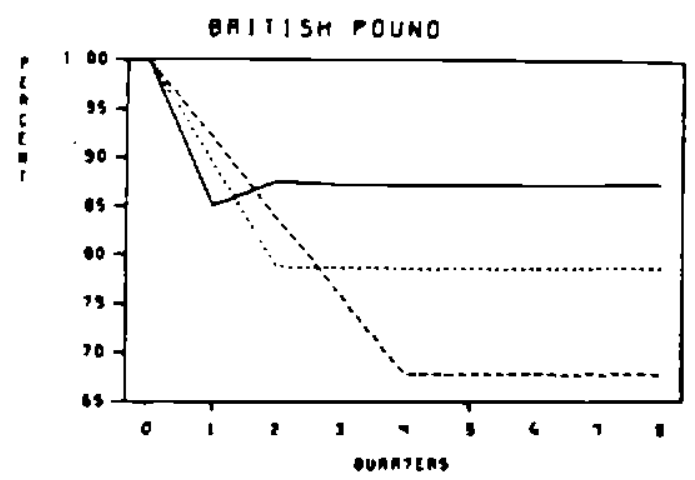

Figure 16

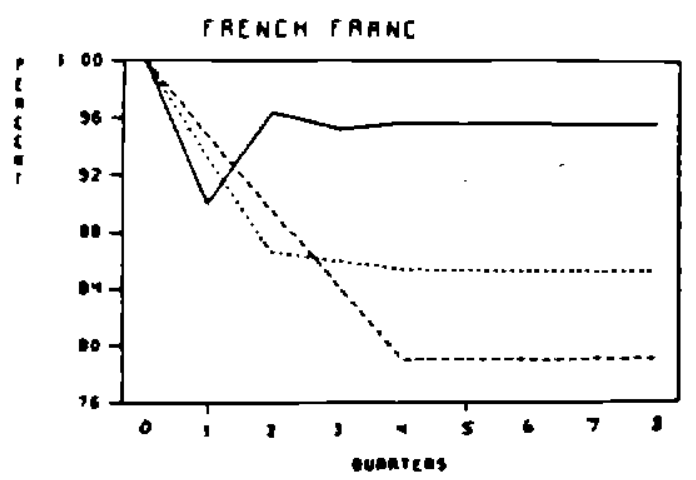

Figute 18

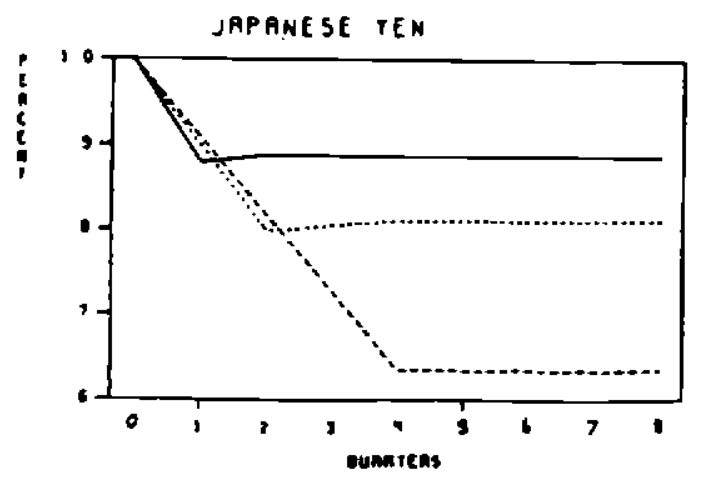

Fiquze 15

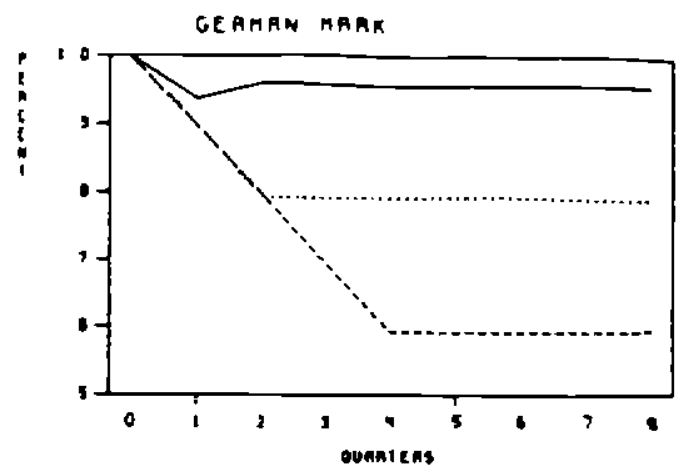

Igure 17

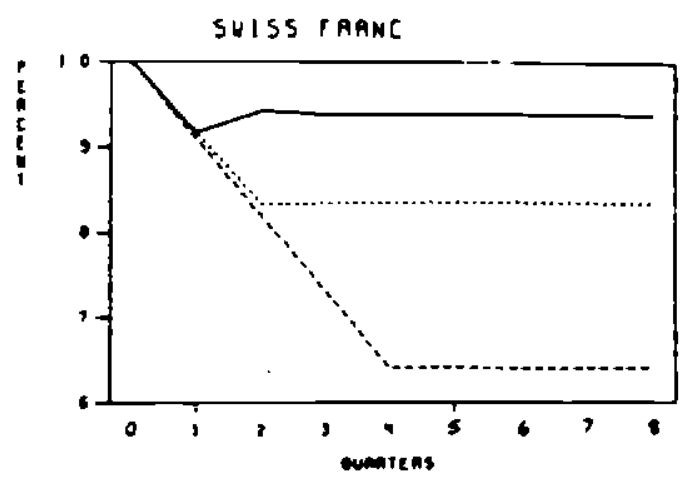

340

$6 H O$

$-$ 
MAS NES YORX DATA
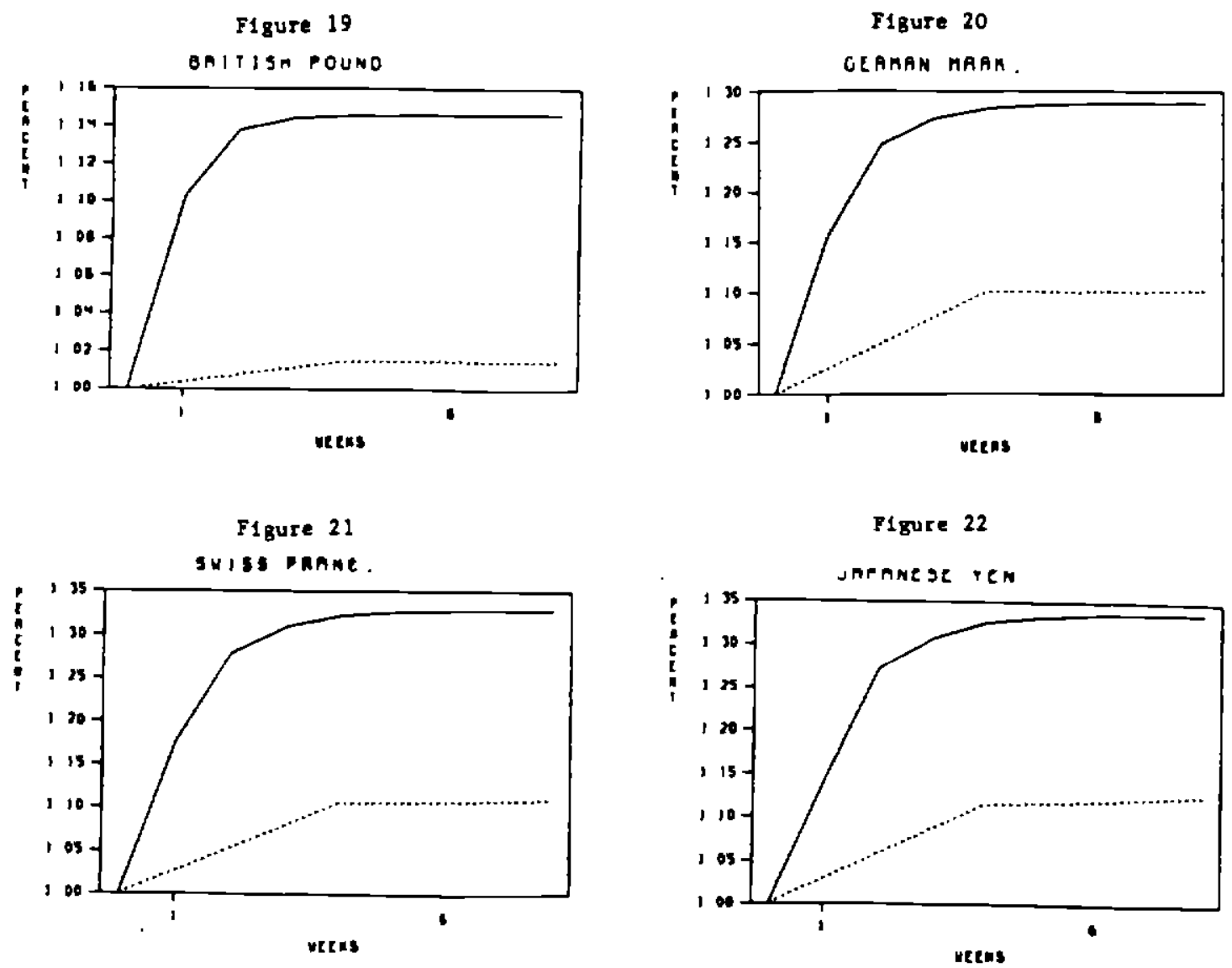

\begin{tabular}{|ll|}
\hline $\begin{array}{l}14 x \\
\text { ind }\end{array}$ & $-\ldots$ \\
\hline
\end{tabular}


MAS LONDON DATA

Figure 23

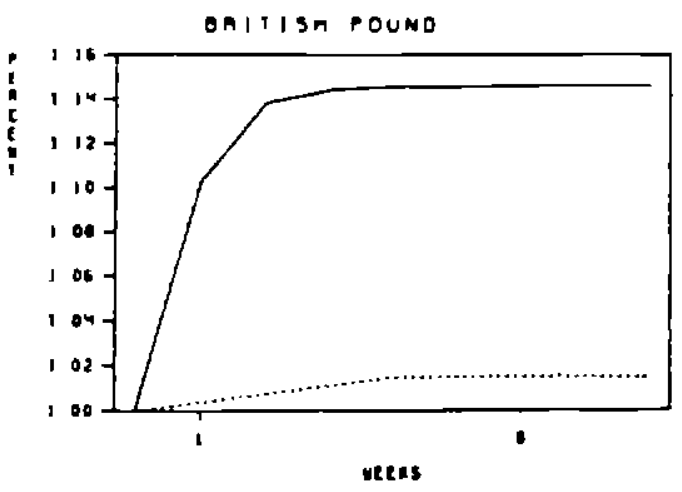

Figure 25

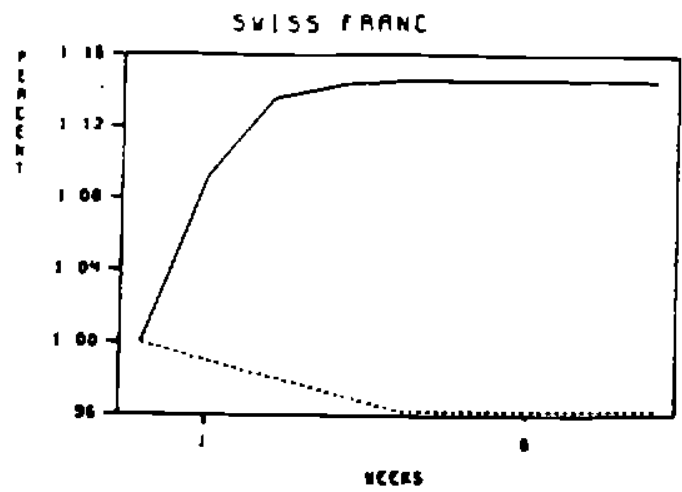

F1 gure 24

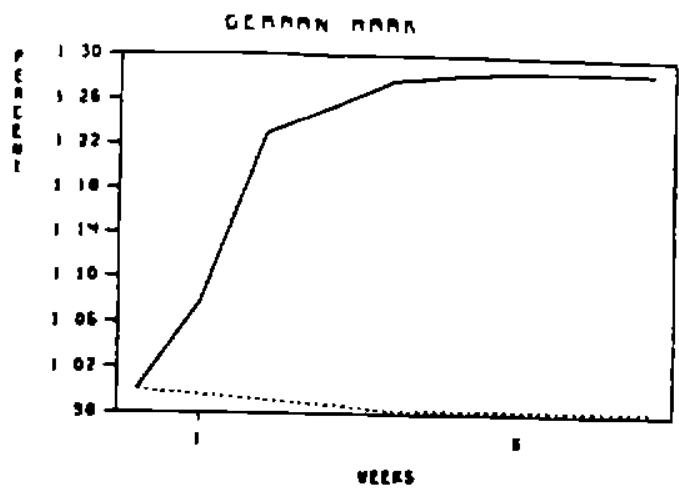

P1 gure 26

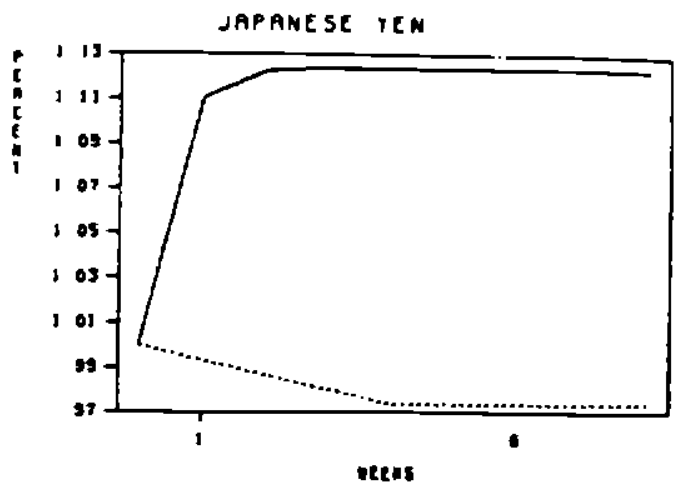

\section{$14 k$}


Table 2

Economist Survey

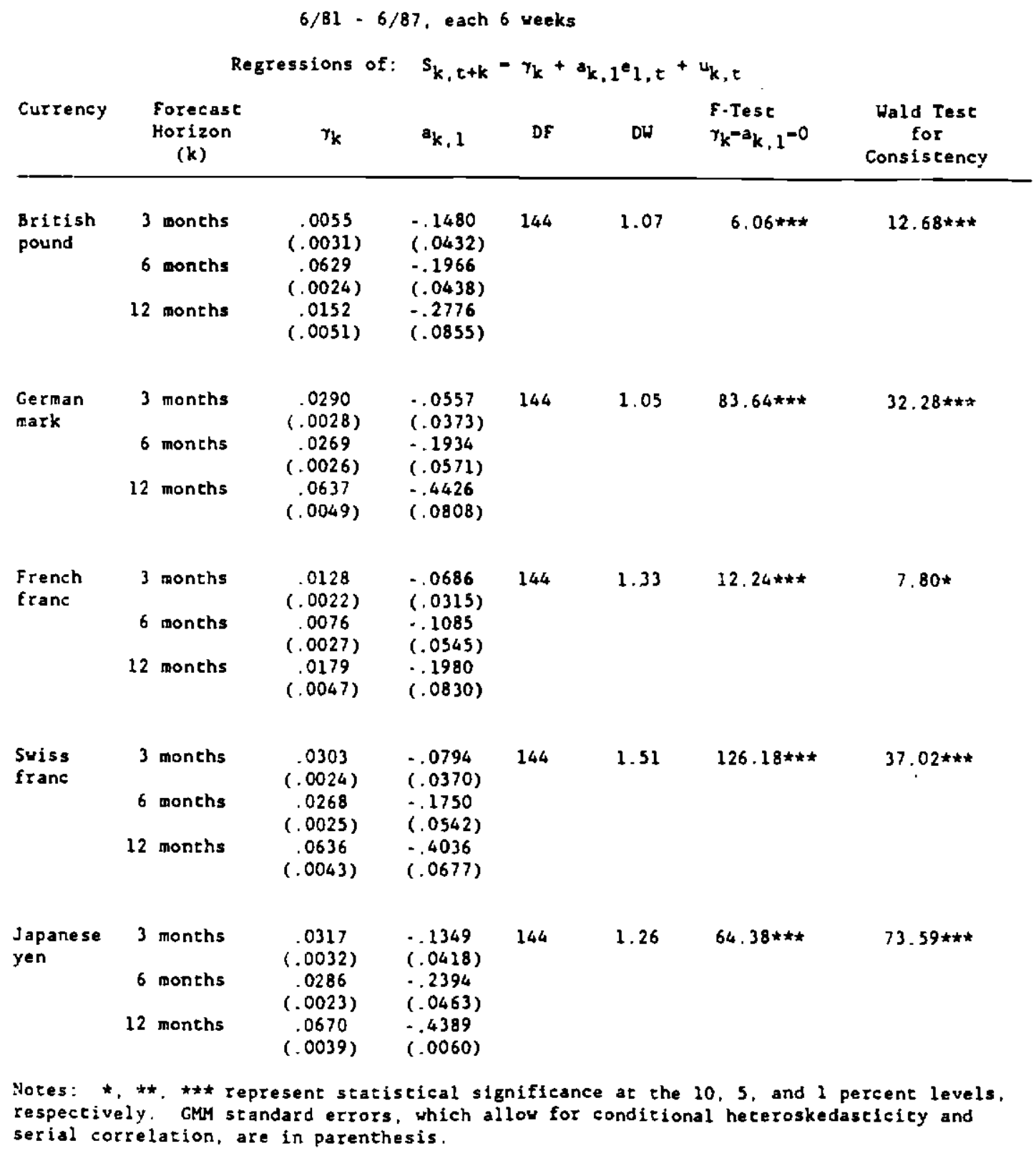


Table 3

New York MMS Survey

$4 / 84-4 / 87$, weekly

Regressions of $S_{k, t+k}=r_{k}+a_{k, 1} e_{1, t}+u_{k, t}$

\begin{tabular}{|c|c|c|c|c|c|c|c|}
\hline Currency & $\begin{array}{l}\text { Forecast } \\
\text { Horizon } \\
(k)\end{array}$ & $\gamma_{k}$ & ${ }^{a} k, 1$ & DF & DW & $\begin{array}{l}F \text {-Test } \\
\gamma_{k}=a_{k}, l^{-0}\end{array}$ & $\begin{array}{l}\text { Wald Test } \\
\text { for } \\
\text { Consistency }\end{array}$ \\
\hline \multirow[t]{2}{*}{$\begin{array}{l}\text { British } \\
\text { pound }\end{array}$} & I week & $\begin{array}{l}-.0015 \\
(.0008)\end{array}$ & $\begin{array}{l}.1026 \\
(.0424)\end{array}$ & 220 & 1.69 & $2.63 \star \star \star$ & 0.82 \\
\hline & 1 month & $\begin{array}{l}.0025 \\
(.0013)\end{array}$ & $\begin{array}{l}.0099 \\
(.0925)\end{array}$ & & & & \\
\hline \multirow[t]{2}{*}{$\begin{array}{l}\text { German } \\
\text { mark }\end{array}$} & 1 week & $\begin{array}{l}.0022 \\
(.0011)\end{array}$ & $\begin{array}{l}.1604 \\
(.0502)\end{array}$ & 220 & $1.64^{\circ}$ & $6.17 * \pi *$ & 1.75 \\
\hline & 1 month & $\begin{array}{l}.0031 \\
(.0015)\end{array}$ & $\begin{array}{l}.1118 \\
(.1025)\end{array}$ & & & & \\
\hline \multirow[t]{2}{*}{$\begin{array}{l}\text { Swiss } \\
\text { franc }\end{array}$} & I week & $\begin{array}{l}.0029 \\
(.0009)\end{array}$ & $\begin{array}{l}.1866 \\
(.0430)\end{array}$ & 219 & 1.77 & $10.04 * \star \star$ & $5.35 *$ \\
\hline & 1 month & $\begin{array}{l}.0036 \\
(.0014)\end{array}$ & $\begin{array}{l}.1152 \\
(.0892)\end{array}$ & & & & \\
\hline \multirow[t]{2}{*}{$\begin{array}{l}\text { Japanese } \\
\text { yen }\end{array}$} & 1 week & $\begin{array}{l}.0021 \\
(.0007)\end{array}$ & $\begin{array}{l}.1573 \\
(.0540)\end{array}$ & 220 & 1.68 & $9.59^{\star} \star \star$ & 1.85 \\
\hline & 1 month & $\begin{array}{l}.0042 \\
(.0010)\end{array}$ & $\begin{array}{l}.1474 \\
(.0651)\end{array}$ & & & & \\
\hline
\end{tabular}

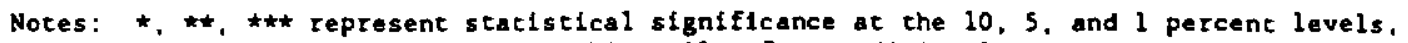
respectively. GM standard errors, which allow for condltional heteroskedasticlty and seri correlation, are in parenthesis. 
Table 4

London Mas Survey

$4 / 84-4 / 87$, weekly

\begin{tabular}{|c|c|c|c|c|c|c|c|}
\hline \multicolumn{8}{|c|}{ Regressions of $s_{k, t+k}-{ }_{\gamma_{k}}+a_{k, 1} e_{1, t}+u_{k, t}$} \\
\hline Currency & $\begin{array}{l}\text { Forecast } \\
\text { Horizon } \\
\text { (k) }\end{array}$ & ${ }^{\gamma_{k}}$ & $a_{k, 1}$ & DF & $D W$ & $\begin{array}{l}\text { F-Test } \\
\gamma_{k}-a_{k, 1}=0\end{array}$ & $\begin{array}{l}\text { Wald Test } \\
\text { for } \\
\text { Consistency }\end{array}$ \\
\hline
\end{tabular}

\begin{tabular}{|c|c|c|c|c|c|c|c|}
\hline \multirow[t]{2}{*}{$\begin{array}{l}\text { British } \\
\text { pound }\end{array}$} & I week & $\begin{array}{l}-.0014 \\
(.0009)\end{array}$ & $\begin{array}{l}.0293 \\
(.0435)\end{array}$ & 201 & 1.93 & 1.27 & 1.62 \\
\hline & l month & $\begin{array}{l}-.0006 \\
(.0013)\end{array}$ & $\begin{array}{l}-.0591 \\
(.1099)\end{array}$ & & & & \\
\hline \multirow[t]{2}{*}{$\begin{array}{l}\text { German } \\
\text { mark }\end{array}$} & l veek & $\begin{array}{l}.0015 \\
(.0008)\end{array}$ & $\begin{array}{c}.0810 \\
(.0435)\end{array}$ & 205 & 1.92 & $3.09 \star \star \star$ & 0.11 \\
\hline & 1 month & $\begin{array}{l}.0040 \\
(.0016)\end{array}$ & $\begin{array}{l}.0602 \\
(.1058)\end{array}$ & & & & \\
\hline \multirow[t]{2}{*}{$\begin{array}{l}\text { Suiss } \\
\text { franc }\end{array}$} & l week & $\begin{array}{l}.0016 \\
(.0011)\end{array}$ & $\begin{array}{c}.0961 \\
(.0484)\end{array}$ & 203 & 1.89 & $2.75 * * *$ & 0.34 \\
\hline & 1 month & $\begin{array}{l}.0034 \\
(.0016)\end{array}$ & $\begin{array}{c}.0515 \\
(.0882)\end{array}$ & & & & \\
\hline \multirow[t]{2}{*}{$\begin{array}{l}\text { Japanese } \\
\text { yen }\end{array}$} & l week & $\begin{array}{l}.0009 \\
(.0006)\end{array}$ & $\begin{array}{c}.1182 \\
(.0472)\end{array}$ & 204 & 1.83 & $3.91 * \pm *$ & 0.07 \\
\hline & 1 monch & $\begin{array}{l}.0035 \\
(.0013)\end{array}$ & $\begin{array}{c}.1266 \\
(.0775)\end{array}$ & & & & \\
\hline
\end{tabular}

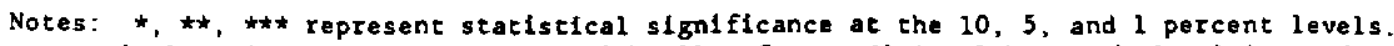
respectively. GM standard errors, which allow for conditlonal heteroskedasticity and serial correlation, are in parenthesis. 
Table 5

Economist Survey

$6 / 81 \cdot 6 / 87$, each 6 weeks

Regressions of: $s_{k, t+k}-\gamma_{k}+a_{k, 1} e_{1, t}+s_{k, 2^{e}} 1, t-1+u_{k, t}$

\begin{tabular}{|c|c|c|c|c|c|c|c|c|}
\hline Currency & $\begin{array}{l}\text { Forecast } \\
\text { Horizon } \\
\text { (k) }\end{array}$ & $r k$ & $a_{k}, 1$ & $a_{k} \cdot 2$ & DF & DW & $\begin{array}{l}\begin{array}{l}F \cdot \text { Test } \\
k=a_{k} \cdot 1^{-a_{k}} \cdot 2 \\
=0\end{array}\end{array}$ & $\begin{array}{l}\text { Wald Test } \\
\text { for } \\
\text { Consistency }\end{array}$ \\
\hline $\begin{array}{l}\text { British } \\
\text { pound }\end{array}$ & $\begin{array}{l}3 \text { months } \\
6 \text { months } \\
12 \text { months }\end{array}$ & $\begin{array}{l}.0057 \\
(.0028) \\
.0063 \\
(.0026) \\
.0150 \\
(.0042)\end{array}$ & $\begin{array}{l}-.1496 \\
(.0490) \\
-.2117 \\
(.0499) \\
-.3225 \\
(.0804)\end{array}$ & $\begin{array}{l}.0037 \\
(.0490) \\
.0270 \\
(.0569) \\
. .1282 \\
(.0794)\end{array}$ & 141 & 1.05 & 5. $39 * *$ & $19.48 * * *$ \\
\hline $\begin{array}{l}\text { German } \\
\text { mark }\end{array}$ & $\begin{array}{l}3 \text { months } \\
6 \text { months } \\
12 \text { months }\end{array}$ & $\begin{array}{l}.0290 \\
(.0030) \\
.0282 \\
(.0023) \\
.0662 \\
(.0036)\end{array}$ & $\begin{array}{l}-.0632 \\
(.0459) \\
-.2079 \\
(.0607) \\
-.4080 \\
(.0659)\end{array}$ & $\begin{array}{l}.0185 \\
(.0468) \\
.0519 \\
(.0527) \\
. .2860 \\
(.0560)\end{array}$ & 141 & 1.10 & $81.53 \star \star \star$ & 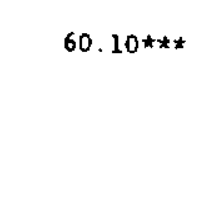 \\
\hline $\begin{array}{l}\text { French } \\
\text { frane }\end{array}$ & $\begin{array}{l}3 \text { months } \\
6 \text { months } \\
12 \text { months }\end{array}$ & $\begin{array}{l}.0135 \\
(.0020) \\
.0075 \\
(.0025) \\
.0175 \\
(.0043)\end{array}$ & $\begin{array}{l}-.1000 \\
(.0390) \\
.1349 \\
(.0698) \\
. .2095 \\
(.1003)\end{array}$ & $\begin{array}{l}.0541 \\
(.0373) \\
.0321 \\
(.0540) \\
.0643 \\
(.0776)\end{array}$ & 141 & 1.37 & $9.91 * \hbar \star$ & $25.12 \star \star \star$ \\
\hline $\begin{array}{l}\text { Swiss } \\
\text { frane }\end{array}$ & $\begin{array}{l}3 \text { months } \\
6 \text { months } \\
12 \text { months }\end{array}$ & $\begin{array}{l}.03008 \\
(.0028) \\
.0297 \\
(.0023) \\
.0657 \\
(.0034)\end{array}$ & $\begin{array}{l}-.0823 \\
(.0401) \\
-.1654 \\
(.0548) \\
-.3599 \\
(.0547)\end{array}$ & $\begin{array}{l}.0187 \\
(.0334) \\
.0671 \\
(.0491) \\
.02187 \\
(.0486)\end{array}$ & 141 & 1.40 & $79.53 \star \star \star$ & $71.14 \star \star \star$ \\
\hline $\begin{array}{l}\text { Japanese } \\
\text { yen }\end{array}$ & $\begin{array}{l}3 \text { months } \\
6 \text { months } \\
12 \text { months }\end{array}$ & $\begin{array}{l}.0311 \\
(.0036) \\
.0296 \\
(.0022) \\
.0687 \\
(.0032)\end{array}$ & $\begin{array}{l}-.1197 \\
(.0441) \\
-.2020 \\
(.0437) \\
-.3664 \\
(.0521)\end{array}$ & $\begin{array}{l}-.0064 \\
(.0424) \\
. .1256 \\
(.0455) \\
-.2678 \\
(.0488)\end{array}$ & 141 & 1.22 & $80.50 * * *$ & $142.88 \pi \star \star$ \\
\hline
\end{tabular}

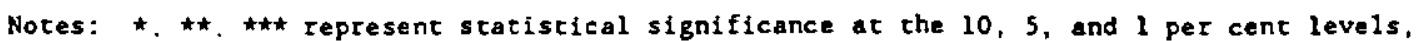
respectively. GMM standard errors. Which allow for conditional heteroskedasticity and serial correlation, are in parenthesis. 
Table 6

Nev Yark MS Survey

$4 / 84-4 / 87$, weekly

Regressions of $s_{k, t+k}=\gamma_{k}+a_{k, 1} e_{1, t}+a_{k, 2}{ }^{e} 1, t-1+{ }_{k, t}$

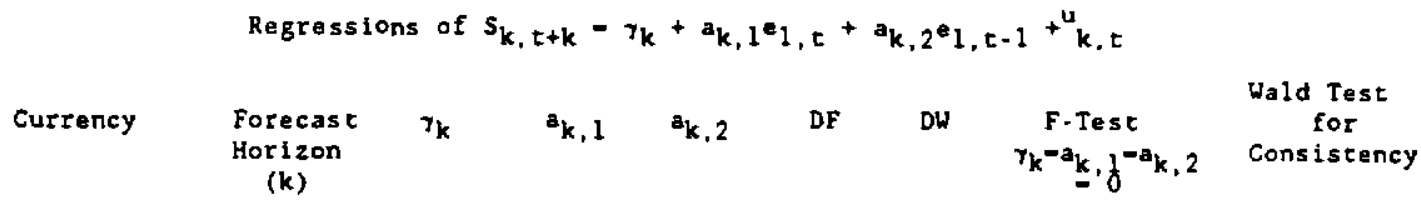

\begin{tabular}{|c|c|c|c|c|c|c|c|c|}
\hline \multirow[t]{2}{*}{$\begin{array}{l}\text { British } \\
\text { pound }\end{array}$} & 1 week & $\begin{array}{l}-.0015 \\
(.0008)\end{array}$ & $\begin{array}{l}.1024 \\
(.0415)\end{array}$ & $\begin{array}{l}.0223 \\
(.0835)\end{array}$ & 216 & 1.69 & $2.10 \star$ & 1.37 \\
\hline & 1 month & $\begin{array}{l}-.0024 \\
(.0013)\end{array}$ & $\begin{array}{l}.0164 \\
(.0933)\end{array}$ & $\begin{array}{l}.0009 \\
(.1191)\end{array}$ & & & & \\
\hline \multirow[t]{2}{*}{$\begin{array}{l}\text { German } \\
\text { mark }\end{array}$} & 1 week & $\begin{array}{l}.0019 \\
(.0009)\end{array}$ & $\begin{array}{l}.1527 \\
(.0509)\end{array}$ & $\begin{array}{l}.0694 \\
.0635\end{array}$ & 216 & 1.65 & $4.36+x k x$ & 3.03 \\
\hline & 1 month & $\begin{array}{l}.0031 \\
(.0015)\end{array}$ & $\begin{array}{l}.0991 \\
(.1050)\end{array}$ & $\begin{array}{c}.0933 \\
(.1075)\end{array}$ & & & & \\
\hline \multirow[t]{2}{*}{$\begin{array}{l}\text { Swiss } \\
\text { franc }\end{array}$} & 1 week & $\begin{array}{l}.0027 \\
(.0008)\end{array}$ & $\begin{array}{l}.1787 \\
(.0424)\end{array}$ & $\begin{array}{l}.0692 \\
.0453\end{array}$ & 215 & 1.78 & $8.01 * x *$ & $10.992 \times$ \\
\hline & 1 month & $\begin{array}{l}.0034 \\
(.0014)\end{array}$ & $\begin{array}{l}.1060 \\
(.0871)\end{array}$ & $\begin{array}{l}.1030 \\
(.0814)\end{array}$ & & & & \\
\hline \multirow[t]{2}{*}{$\begin{array}{l}\text { Japanese } \\
\text { yen }\end{array}$} & 1 week & $\begin{array}{l}.0017 \\
(.0007)\end{array}$ & $\begin{array}{l}.1419 \\
(.0567)\end{array}$ & $\begin{array}{c}.1107 \\
(.0563)\end{array}$ & 216 & 1.65 & $9.73 * * t$ & $11.15 * \star$ \\
\hline & 1 month & $\begin{array}{l}.0037 \\
(.0010)\end{array}$ & $\begin{array}{l}.1150 \\
(.0694)\end{array}$ & $\begin{array}{c}.2254 \\
(.0697)\end{array}$ & & & & \\
\hline
\end{tabular}

Notes: \#, \#, \#* represent statistical significance at the 10 , 5 , and 1 percent levels. respectively. G.M standard errors. Which allow for condicional heceroskedasticicy and seri correlation, are in parenthesis. 
Table ?

London ays Survey

$4 / 84 \cdot 4 / 87$, weekly

Regressions of $s_{k, t+k}-\gamma_{k}+a_{k, 1} e_{1, c}+a_{k, 2} e_{1, t-1}+u_{k, c}$

\begin{tabular}{|c|c|c|c|c|c|c|c|c|}
\hline urrency & $\begin{array}{l}\text { Forecast } \\
\text { Horizon } \\
\text { (k) }\end{array}$ & $\gamma_{k}$ & $a_{k, 1}$ & $a_{k, 2}$ & DF & DU & $\begin{array}{r}\text { F-Test } \\
\gamma_{k}=s_{k}, j^{-}\end{array}$ & $\begin{array}{c}\text { Wald Test } \\
\text { for } \\
\text { Consistency }\end{array}$ \\
\hline
\end{tabular}

\begin{tabular}{|c|c|c|c|c|c|c|c|}
\hline $\begin{array}{l}\text { British } \\
\text { pound }\end{array}$ & 1 week & $\begin{array}{l}-.0014 \\
(.0007)\end{array}$ & $\begin{array}{l}.0296 \\
(.0443)\end{array}$ & $\begin{array}{l}.0258 \\
(.0428)\end{array}$ & 198 & 1.95 & 0.78 \\
\hline . & 1 month & $\begin{array}{l}-.0007 \\
(.0013)\end{array}$ & $\begin{array}{l}-.0519 \\
(.1172)\end{array}$ & $\begin{array}{c}.0361 \\
(.0846)\end{array}$ & & & \\
\hline
\end{tabular}

$\begin{array}{llccccccc}\begin{array}{l}\text { German } \\ \text { mark }\end{array} & 1 \text { week } & .0014 & .0775 & .0604 & 202 & 1.97 & 3.59 * \star \star & 2.09 \\ & & (.0007) & (.0421) & (.0405) & & & & \\ & 1 \text { month } & .0037 & .0689 & .1238 & & & \\ & & (.0017) & (.1096) & (.0906)\end{array}$

$\begin{array}{llccccccc}\text { Swiss } & 1 \text { week } & .0015 & .0928 & .0552 & 200 & 1.89 & 2.29 * \star * & 2.67 \\ \text { franc } & & (.0012) & (.0487) & (.0488) & & & & \\ & & & & & & \\ & 1 \text { month } & .0033 & .0582 & .1076 & & & \\ & & (.0016) & (.0928) & (.1007)\end{array}$

$\begin{array}{llccccccc}\text { Japanese } & 1 \text { week } & .0007 & .1104 & .0839 & 201 & 1.87 & 4.20 * * \star & 2.26 \\ \text { yen } & & (.0006) & (.0414) & (.0437) & & & & \end{array}$

1 monch $\quad .0037 \quad .1106 \quad .0830$

Notes: $\star \star, \star, \star \star \star$ represent statistical significance at the 10,5 , and 1 percent levels, respectively. GMM standard errors, which allow for conditional heceroskedasticity and serial correlation. are in parenthesis. 